\title{
スポーツ動作における力学的モデリング
}

\author{
浅井 武
}

\section{Mechanical modeling in sports motion}

\author{
Takeshi Asai
}

\begin{abstract}
The present paper provides a broad overview of the three main dynamic models-the rigid body model, the deformation (deformable body) model, and the fluid structure model-that are used when investigating physical exercise and sports techniques from a biomechanical or ergonomic standpoint. The benefits of such models and the precautions that should be taken in their use and interpretation are investigated, as are some potential future models. Rigid body system models, among which the mass-spring model and rink-segment model are the most common, have conventionally been the core models in the fields of physical education and sport. This type of model will likely continue to evolve and be applied to various problems. At the same time, it is true that rigid body models are ill-suited to the study of certain techniques. For this reason, deformation and fluid structure models have been developed for use in such research and for problem solving. Analyses using conventional physical education and sport models usually describe sporting techniques in detail by calculating joint torque based on kinematic data from actual movement coordinates in an inverse dynamic manner (inputting displacement and outputting force). This has, to date, produced outstanding results, providing a "description" of the action taking place. In future, analyses that incorporate direct dynamics (inputting force and outputting displacement) based on elicited force will also be required in conjunction with this descriptive approach. A combination of these two approaches will enable simple "predictions" to be carried out on an appropriate level. The ultimate goal of such predictions will be to optimize the performance of the technique. In future, therefore, it will be important to perform modeling that incorporates description and prediction, yielding a model for optimization of the action.
\end{abstract}

\section{Key words : model, rigid body, FEM, CFD}

(Japan J. Phys. Educ. Hlth. Sport Sci. 51: 241-251, May, 2006)

筑波大学大学院人間総合科学研究科

干 305-8574＼cjkstart茨城県つくば市天王台 1-1-1

連絡先 浅井 武
Comprehensive Human Sciences, University of Tsukuba 1-1-1, Tennodai, Tsukuba, Ibaraki, 305-8574

Correspondingauthor asai@taiiku.tsukuba.ac.jp 
キーワード: モデル, 剛体, 有限要素法, 数值流 体力学

\section{Iはじめに}

スポーツ技術を検討したり，分析したりする場 合, 先ず, その現象や運動を観察し, その運動様 式や形態を知ることが大切である。 そして，その 現象や運動を, 主観的にしろ, 客観的しろ, 詳細 に検討し, 動作の改善や運動の指導に結び付けて いくことになる。このアプローチは科学の基本的 姿勢の一つであり，これまで大きな成果を上げ， 今後も成果を上げ続けると考えられる. しかし, その現象や運動の背後にあるメカニズムやルール を検討しようとする場合，観察だけでは不十分な 場合が少なくない（Sakashita，2002）。そのよう な場合, 対象の現象や運動を簡略化や焦点化した モデルを考え，その性質から対象の現象を検討す ると，見通しがよくなる場合が多い。このモデル を立てて現象を分析したり，説明するアプローチ も, 科学の常套手段であり, 脳モデル, メンタル モデル, 経済モデル等々, 自然科学領域だけでな く, 人文・社会科学領域にも広く使われている.

身体運動やスポーツ技術を，バイオメカニクス 的, あるいは工学的に検討する場合, 力学系モデ ル考える場合が多い（深代, 2000). その母体と なる力学は, 基本的に「剛体の力学」「変形体の 力学」及び「流体の力学」から成り立っている. もちろん, 実際の現象は, これらが複雑に関係し ており, 詳細がよく分かっていない力学現象も 多々みうけられる. また, 力学モデルといっても, 風洞実験で用いるスキージャンパーのダミー人形 のように，実体のある物理モデルや，コンピュー タシミュレーションで用いられるように, 現象を 数式に置き換えた数式モデル等に分けられ（阿 江・藤井，2002），どちらかに特化して，あるい は両方を併用して研究が進められているのが現状 であろう. 本論では, 身体運動やスポーツ技術を, バイオメカニクス的，あるいは工学的に検討する 場合によく用いられる力学系モデルを，剛体系モ デル，変形体系モデル，流体系モデルの順に概観
し，その長所や留意点を検討すると共に，モデリ ングに関する今後を展望する。

\section{II 剛体系モデル}

剛体系モデルの最も単純なものとしては, 質点, あるいはそれと類似した概念でモデル化するもの が上げられる，質点とは，位置及び質量のみを有 し，大きさを有しないものである。これは，物体 の質量中心にその全質量が集まったものという考 え方もでき，回転運動を考えない，質量のある剛 体の並進運動を扱うことと同じである．簡単にい えば, 重さのある点で運動を表すことといえよう。 したがって，人やボールの動きを点で代表させて 考えたり,身体重心の運動を分析したりするのに, よく用いられている.

例えば，歩行運動時と走運動時の重心の軌跡や 床反力等に関する研究は数多く行われてきている (Heglund et al., 1995). 歩行時の身体重心の運 動軌跡は, 片足支持期にもっとも高い位置となり, 両足支持期に低い位置となる（図 1).これは, 倒立振子の運動と類似しており, エネルギー効率 のよさが指摘されている. 一方, 同じ移動運動で

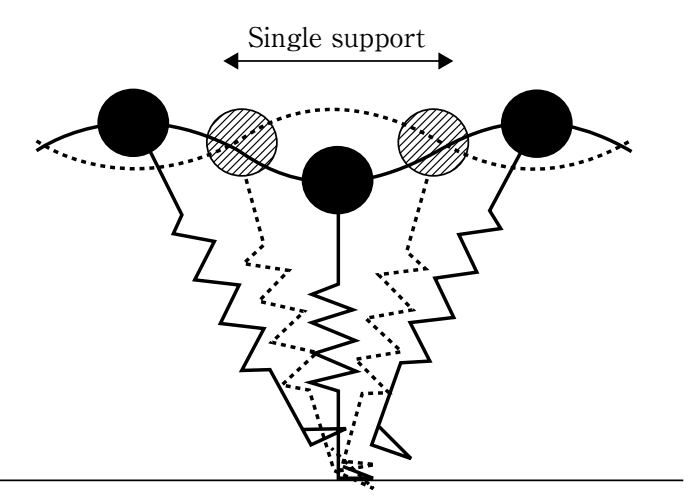

図1 質量一バネ系モデルによる歩行運動（斜線）と走運 動（黒ソリッド）の重心変動模式図. 歩行時の身体重心 の運動軌跡は，片足支持期にもっとも高い位置となり， 両足支持期に低い位置となる，それに対して走運動時て は, 片足支持期に最も低い位置となり, 遊脚時（両足支 持期は無い）に高い位置となる. 変位や運動周期は異な るが, 歩行運動と走運動は, 逆位相的な運動となってい る. 
も，走運動時の身体重心の運動軌跡は，片足支持 期に最も低い位置となり，遊脚時（両足支持期は 無い）に高い位置となる。変位や運動周期は異な るが，歩行運動とは，片足支持期において逆位相 的な運動となっていることが興味深い。また，歩 行時及び走運動時の脚を質量一バネ系モデルで近 似し，バネの剛性（stiffness）と運動周期を変え ることにより，実際の歩行時及び走運動時と類似 した運動で移動が実現されることが報告されてい る(Seyfarth et al., 2002)。もちろん，バネ自体 は剛体ではなく, 弾性要素の典型的モデルである が，質点系や剛体系と関連してモデリングに用い られることが多いので，本論では，剛体系モデル の項でバネモデルを含めて説明することにする.

単純な 1 次元の質量一バネ系モデルの運動方程 式は，式（1）のようになる。これに重力を加え ると式（2）になり，必要に応じて粘性抵抗を入 れることもできる（式（3））。このような，単純 な質量一バネ系モデルの場合, 運動方程式も極め て簡単な形となり，解析的に解を求めること（微 分方程式の一般解として代数方程式を求めるこ と）も不可能ではない。 もちろん, 要素や自由度 を増やすことによって解析的に解を求めるのは困 難になるが, 数值解であれば比較的容易である.

このように，身体重心の運動をモデル化して考 えると，四肢の細かい運動は分析しにくいという 短所はあるものの, 運動方程式への定式化が簡単, パラメータの影響が推測しやすい等の長所もあ り，依然として有効な方法であると考えられる。 $m \ddot{x}=-k x$

$m \ddot{x}=m g-k x$

$m \ddot{x}=m g-k x-c \dot{x}$

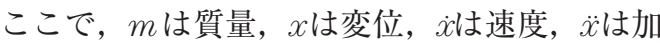
速度, $k$ は弾性係数 (バネ剛性), $g$ は重力加速度, cは粘性係数を示す.

質点や重心モデルは，3次元空間においては 3 方向の並進運動を考えればよい。しかし，身体部 位などの体積のある物体を剛体として考える場 合, 3 次元空間においては 3 方向の並進運動とそ の軸回りの 3 方向の回転運動を考慮する必要があ る.つまり，拘束のない一つの剛体の自由度は 6
であり，運動を記述するためには，基本的に $6 つ$ の運動方程式が必要になる（式（4-1）-(4-6)). $F_{x}=m \ddot{x}$

$F_{y}=m \ddot{y}$

$F_{z}=m \ddot{z}$

$T_{a}=I_{a} \ddot{\theta}_{a}$

$T_{\beta}=I_{\beta} \ddot{\theta}_{\beta}$

$T_{\gamma}=I_{\gamma} \ddot{\theta}_{\gamma}$

ここで, $F_{x}, F_{y}, F_{z}$ は各方向の力, $T_{a}, T_{\beta}, T_{\gamma}$ は各軸回りのトルク (回転力), $\ddot{x}, \ddot{y}, \ddot{z} は$ 各方向 の加速度, $\ddot{\theta}_{a}, \ddot{\theta}_{\beta}, \ddot{\theta}_{\gamma}$ は各軸回りの角加速度, $m$ は質量, $I_{a}, I_{\beta}, I_{\gamma}$ は各軸回りの慣性モーメン トを示す。

並進運動の式（(4-1）-（4-3））に出てくる質 量は，どの方向でも同じ值であるが，回転運動の 式（(4-4）-（4-6））に出てくる回転の慣性抵抗 ともいえる慣性モーメント（回転のしにくさ）は， 回転軸によって異なるので注意が必要である。そ して，この剛体が幾つか集まったものとして，身 体をモデリングし，剛体系モデルとしてょく用い られるのが，リンク・セグメントモデル（Winter，1990）やマルチボディシステム（Haug, 1995）である。リンク・セグメントモデルは，解 剖学的データや力学的データを基に, 逆動力学で 運動中の関節トルクを求めるのによく用いられ， 剛体系のアプローチとして極めて重要かつ基本的 な手法となっている.

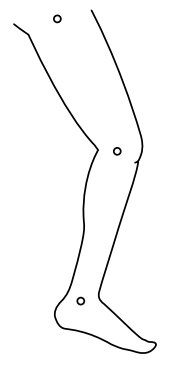

(a)

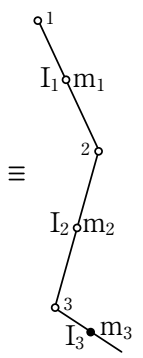

(b)

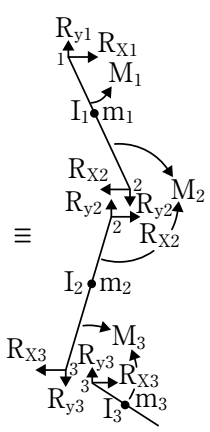

(c)

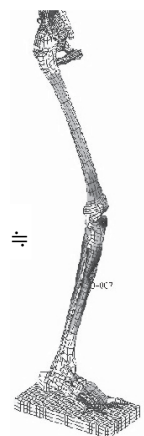

(d)
図2 Winter（1990）がまとめた, 解剖学的モデル (a), リンク・セグメントモデル (b), フリーボデイダイア グラム（c）及び有限要素下肢骨格モデル（d）の関係 (深代と柴山（2000）より著者改変). 
図 2 は,リンク・セグメントモデルの基本的な モデル化の方法を示したものであり，フリーボデ イダイヤグラムを考えると式が導出しやすい（式 (5-1）—-(5-9))。これは, 前述の剛体の運動を2 次元運動として連結したものともいえる。ここで $\mathrm{L}_{\mathrm{nm}}$ は, 各関節の回転軸から部分重心までの距離 を表しており，式（5-1）-（5-3）は足関節，式 （5-4）-（5-6）は膝関節，式（5-7）-（5-9）は 股関節のそれぞれ並進力と回転力（トルク）を表 している.つまり，式（5-3）が足関節トルク， 式（5-6）が膝関節トルク，式（5-9）が股関節卜 ルクを示している.

$R_{x 3}=m a_{x 3}$

$R_{y 3}=m a_{y 3}+m g$

$M_{3}=I_{3} \alpha_{3}+R_{x 3} \times L_{y 3}+R_{y 3} \times L_{x 3}$

$R \times 2=m a_{x 2}+R_{x 3}$

$R_{y 2}=R_{y 3}+m a_{y 2}+m g$

$M_{2}=I_{2} \alpha_{2}+M_{3}+R_{x 3} \times L_{y 2}-R_{y 3} \times L_{x 2}+R_{x 2} \times L_{y 2}-$

$R_{y 2} \times L_{x 2}$

$R_{x 1}=m a_{x 1}+R_{x 2}$

$R_{y 1}=R_{y 2}+m a_{y 1}+m g$

$M_{1}=I_{1} \alpha_{1}+M_{2}+R_{x 2} \times L_{y 1}-R_{y 2} \times L_{x 1}+R_{x 1} \times L_{y 1}-$

$$
R_{y 1} \times L_{x 1}
$$

伊藤ほか（1998）は，同様のリンク・セグメン トモデルを用いて $100 \mathrm{~m}$ 中間疾走局面における走 動作を分析した．その結果，もも上げの高さと疾 走速度とに相関がみられなかったことや，膝関節 最大進展速度と疾走速度に逆相関が見られたこと から, 脚のスイング運動を中心とし, 脚全体のス ティフネスを高くしたキック動作が速いランナー の特徴であることを明らかにしている。投動作に ついてもリンク・セグメントモデルを用いて，関 節トルクやエネルギーの流れの観点等から, 精力 的に研究が進められている (Sakurai et al., 1993 ; 宮西ほか, 1997 ; Matsuo et al., 2002 ; 島田ほか，2004）。また，ボールキック動作につ いては, Nunomeほか (2002) が, 各種キックの 関節トルクを検討している.

このリンク・セグメントモデルの関節トルク は，基本的にその関節に働く全体のトルク（ネッ トトルク）を示すが，そのトルクをさらに，筋の
起止停止等の解剖学的知見に基づき, 各筋に配分 し，筋の収縮力そのものを推定するモデルに筋一 骨格系モデルがある（Hoy et al., 1992）。しかし， 逆動力学の手法を用いて，関節トルクから筋張力 を求める場合，人間の筋力システムに圥長性があ るため, 不定問題になる場合が多い。そこで現実 にできるだけ近い筋張力を推定するために, Hill の筋肉モデル, 筋線維や腱の自然長, 筋の長さ, 収縮速度等の要素を考慮した様々な最適化手法が 研究されている。

長野・深代（2003）は，同様のモデリング手法 により, 収縮要素, 直列弾性要素, 並列弾性要素 からなる, 筋腱複合体 (Muscle-Tendon Complex）モデルを作成し，その力学的特性について 検討している。 その結果, 体幹の大殿筋などは, 筋束が比較的長いため，重い負荷に対して大きな 仕事が可能であり，逆に末端の下腿三頭筋などは 長い腱を持つため，軽い負荷の時に大きな仕事を 行なうことができることを明らかにしている．さ らに，この筋腱複合体モデルを人体骨格モデルに 適用し，ジャンプ動作に関するシミュレーション も実施されている (Nagano and Gerritsen, 2001). そして, 跳躍高を増加させるための要素として, 筋の最大発揮張力や膝関節伸展筋群が重要である ことが示されている。また，この筋腱複合体の働 きを超音波法によって直接計測することも試みら れており，ジャンプや歩行における等尺性収縮中 の腓腹筋筋繊維は，その力一長さ関係の至適長付 近に調節され，効果的にパワーを発揮しているこ とが示唆されている（川上，2003）。

\section{III変形体系モデル}

剛体系モデルが，質量一バネ系モデルやリン ク・セグメントモデルを中心に発展し, 身体運動 学やスポーツ科学・工学分野に大きく貢献してい ることはいうまでもない.しかし，身体や物体の 変形や応力を問題とするとき, 剛体系モデルで考 えるよりも, 変形体系モデルで考えた方が適当な 場合もある (Asai et al., 2002).

変形体の力学は基本的に固体力学や材料力学に 
基礎を置く．物体の変形を議論する場合，外から 系に加えられた外力（external force）の他に， 内部で働く力の内力（internal force）を考える 必要がある。そして，単位面積あたりの内力を応 力 (stress) という。この応力は, 圧縮する内力 (圧縮応力) p引張る内力（引張り応力） からな る垂直応力と横ズレの内力からなるせん断応力に 分類できる. 数学的に応力はべクトルのように矢 印のみで表現することが困難であり，テンソルと 呼ばれる物理量として扱われる。変形体は，剛体 とは異なり，外力を受けることにより変形し，そ の変形量を基準となる長さで割った無次元量は, ひずみ（strain）と呼ばれている．数学的には変 位がベクトル量であり，ひずみは応力と同様，テ ンソル量となる（式（6））。したがって，剛体系 の質量一バネ系では, 力一変位の関係を考えるが, 変形体系では, 応力一ひずみの関係を考えること が基礎となる。

$\sigma=\left[\begin{array}{ccc}\sigma_{x} & \tau_{x y} & \tau_{z x} \\ \tau_{x y} & \sigma_{y} & \tau_{y z} \\ \tau_{z x} & \tau_{y z} & \sigma_{z}\end{array}\right]$

ここで， $\sigma$ は応力テンソル， $\sigma_{n}$ は垂直応力, てnmはせん断応力を示す.

この応力一ひずみの関係を使って, 理論的解析 的に変形体系を検討することもあるが,近年では, 計算科学的手法を用いてモデリングし, コンピュ 一夕によって解析することも少なくない，その変 形体系を扱う代表的計算科学手法に有限要素法 (Finite Element Method：FEM) がある。有限 要素法は 1956 年頃にボーイング社のエンジニア と研究者達が，翼の強度計算に利用したのが，工 学的な活用の始まりだとされている(戸川, 1979). 有限要素法の特質は，実際には複雑な形状・性質 を持つ連続体を, 簡単な特性を持つ少部分要素 （メッシュ）に分割し，それを全体的に組み立て て解き，その挙動を推測しようとするところであ る. 有限要素法は, 複雑な形状であっても, メッ シュさえ定義できれば解析でき，実際的問題を扱 えるのが特徵である.もち万ん, 求まる解はあく まで近似解であり，メッシュ分割の精度によって 解が異なってくる場合もあるが，応用範囲が極め
て広範囲なツールとして活用されている。元々， 有限要素法は, 変形体の微小変形に関する理論や 解法からスタートしており，バイオメカニクス領 域やバイオエンジニアリング領域では，骨の線形 静解析等が行なわれていたが (Huiskes and Chao，1983），近年では，接触や骨折を含むダイ ナミックな非線形解析も試みられてきている.

図 2 (d) は有限要素法でモデル化した下肢骨 格モデル例である（Asai et al., 2001）。足部モデ ルは, 23 の骨等からなる硬組織部と, それを結 合する 15 の軟組織部で構成されている（Asai and Murakami，2001). 下肢モデルの妥当性や 基礎特性を検討するため, 線形静解析による無荷 重時と垂直荷重時の変位を比較すると，荷重時に は踵骨要素の底屈方向の回転, 及び横足根, 足根 中足関節での背屈がみられ, それに伴い内側アー チが変形低下する傾向を示した。この運動パタン は屍体（Cadaver）を用いた垂直荷重（300N） 実験（中部・西脇，1998）による変形様式と同様 の傾向を示していると考えられた。その実験にお ける垂直荷重時の内側アーチ高変位は $2.90 \mathrm{~mm}$ と 報告されており，その際の踵骨の低屈方向への回 転角度は $1.83 \mathrm{deg}$.となっていた。本解析結果にお ける内側アーチ高変位は $2.70 \mathrm{~mm}$ を示したが，そ の踵骨モデルの低屈方向への回転角度は $3.0 \mathrm{deg}$ とやや大きな值を示した。これらの結果から, 本 解析モデルは, 垂直荷重に関してある程度妥当な 力学的特性を持つと判断された.

そして，この下肢骨格モデルを適用し，サッカ 一のボールキック時の力学的特性が検討された (Asai et al.，2005). 下肢骨格モデルとボールの 表皮は固体 (変形体) で，ボールの内部空気は流 体でモデリングされており，流体一構造連成解析 となっている（図 3). その結果，インステップ キックに拈いて，インパクトポイントによってボ ールの反発比（ボール速度／蹴り足の速度）や力 積が異なり, 中足骨頭部, 足根骨及びその上部で インパクトすることによって，大きなボール速度 が得られることが示された (図 4). 。た, 反発 比の高い部位でインパクトした場合，インパクト 時のギアリングアクションにより，ボールの飛び 
出し角度も大きくなることが予測された.さらに, 全く同じ位置関係でボールをインパクトしても， 蹴り足の初速度が大きいほど，ボール飛び出し角 度も大きくなると推定された。

また, 同じ下肢骨格モデルの関節角度を変更し, インフロントカーブキックについても実験と合わ せて検討した（Asai et al., 2004). そして, イン フロント部のボールに対する迎え角と, ボール速 度，ボール回転数の関係が予測された（図 5). この図をみて分かるように，迎え角を変化させる ことによって，同じスイングでも，ボール速度が 大きくボール回転数が小さいキックや, ボール速 度が小さくボール回転数が大きいキックなど, 様々な速度と回転数の組み合わせが，トレードオ フの関係で可能になる。しかし，トップ選手のカ
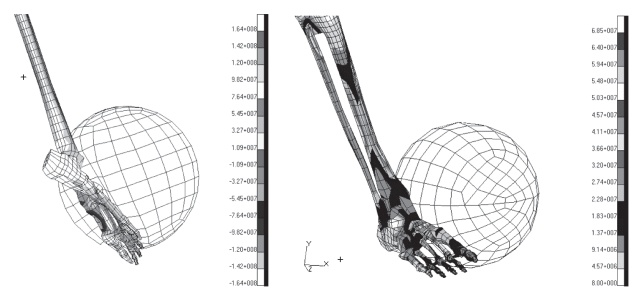

図3 有限要素下肢骨格モデルによる，インステップキッ ク（左）とインフロントカーブキック（右）の応カコン 夕一図

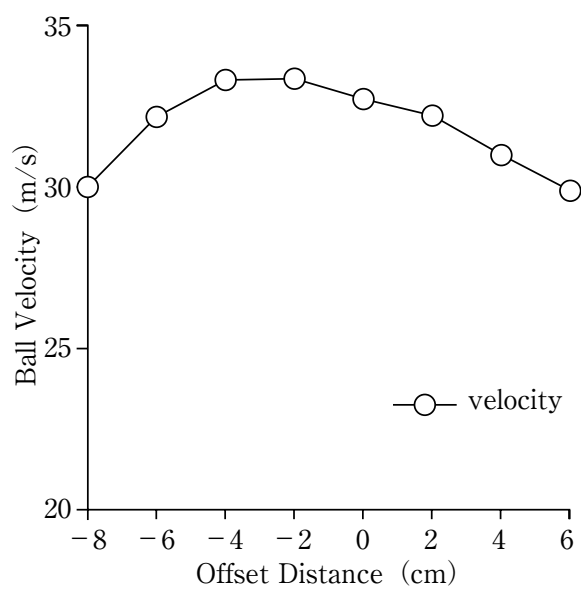

ーブキックのボール速度は $25 \mathrm{~m} / \mathrm{s}$ 以上, 回転数 は10rps 以下の傾向を示し, トップ選手はボール 回転数を最大にする迎え角でなく, ボール回転数 はやや減少するが，比較的大きな並進速度が得ら れる迎え角でキックしていることが示唆された。

このように, 有限要素法では, 手計算ではとて も不可能な解析が実施可能であり, 様々な分野で 広く活用されている。したがって，利用できるツ ールや計算手法も非常に多く，多種多様にわたっ ており, 有限要素法の専門家でなくても容易に実 行できるようになってきている。しかし, 解析結 果は, あくまで開発した数学モデルに対する計算 結果であり, 出力された結果を鵜吞みにするので はなく,その前提となるモデルの単純化の影響や, 境界条件等の効果を踏まえて結果を検討すること が大切である。

\section{IV 流体系モデル}

流体と固体を区別する性質として, 変形のしゃ すさが上げられる（谷，1980）。流体に形の変形 を限りなくゆるやかに与えた場合, 抵抗をほとん ど示さず，その性質は，気体と液体に共通するも のである，もちろん，変形を有限の速さで行なう 場合，その粘性によって抵抗を示すことになる。 また，気体と液体の大きな違いの一つは，圧縮性 であり，気体の体積を縮少させることは比較的容

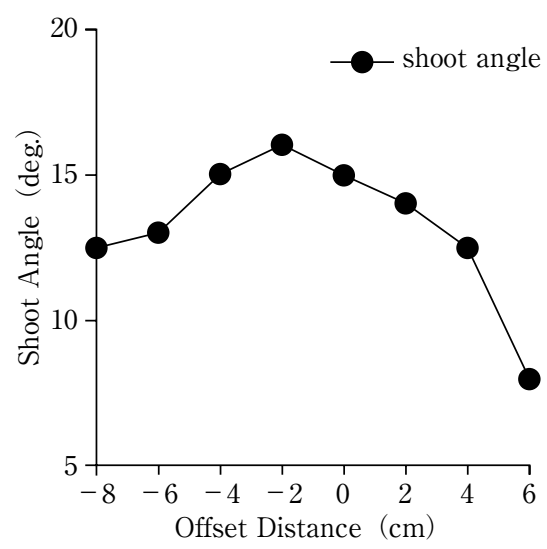

図4 インステップキック時におけるオフセット距離（ボールヒットポイントのズレ幅）とボール速度, 及びオフセット距離とシュートアングル（飛び出し角度） 


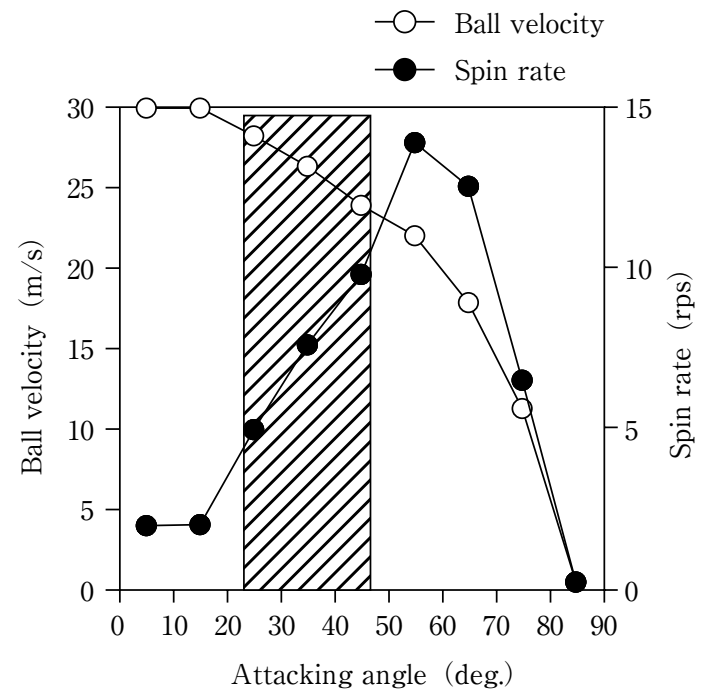

図5 インフロントカーブキックにおけるインパクト部位 の迎え角, ボール速度及びボール回転数の関係. トップ 選手は，高速，低回転レンジ (斜線) のフリーキックが 多い.

易であるが（圧力によって体積や密度が大きく変 わる)，液体の圧縮性は極めて小さく，水に $10^{3}$ 気圧 $(101325 \mathrm{kPa})$ の圧力を加えても，その体積 が $5 \%$ 縮むにすぎない。この流体の基礎方程式は ナビエ-ストークス（Navier-Stokes）方程式（式 （7））であり，解析的に一般解を求めることは困 難である。

$\rho\left(\frac{\partial u}{\partial t}+u \frac{\partial u}{\partial x}+v \frac{\partial u}{\partial y}+w \frac{\partial u}{\partial z}\right)=\rho f_{x}-\frac{\partial p}{\partial x}+\mu \nabla^{2} u$ $\rho\left(\frac{\partial v}{\partial t}+u \frac{\partial v}{\partial x}+v \frac{\partial v}{\partial y}+w \frac{\partial v}{\partial z}\right)=\rho f_{y}-\frac{\partial p}{\partial y}+\mu \nabla^{2} v$ $\rho\left(\frac{\partial w}{\partial t}+u \frac{\partial w}{\partial x}+v \frac{\partial w}{\partial y}+w \frac{\partial w}{\partial z}\right)=\rho f_{z}-\frac{\partial p}{\partial z}+\mu \nabla^{2} w$ $\nabla^{2}=\frac{\partial^{2}}{\partial x^{2}}+\frac{\partial^{2}}{\partial y^{2}}+\frac{\partial^{2}}{\partial z^{2}}$

ここで, $\rho$ は密度， $\mu$ は粘性係数， $x, y, z$, は座標成分， $u, v, w$ は速度成分を示す.

これまで，スポーツにおける流体に関する研究 は, 理論的研究や実験的研究を中心になされてき ており，大きな成果を上げている（Briggs， 1959 ; Mehta, 1983 ; Toussaint, 1991). 実験 的な研究において，生体を対象に実施されること もあるが，風洞実験や流水槽実験等では，模型や

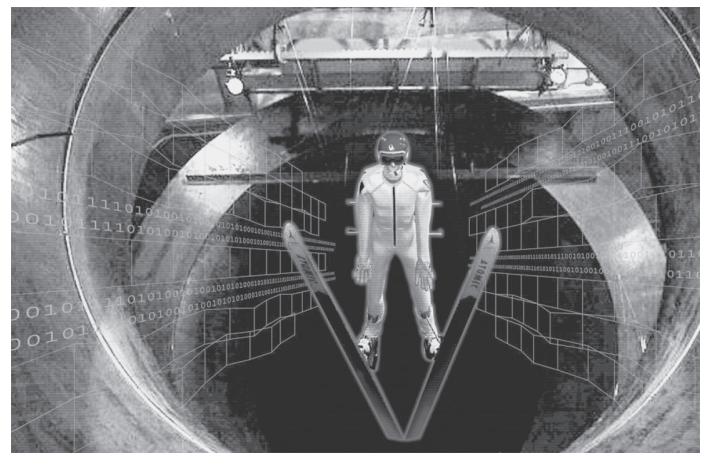

図6 スキージャンパーモデル（物理モデル）を用いた風 洞実験

人体ダミーなどの物理モデルを用いることが多い (図6).

Seo et al. (2004a) は，スキージャンパーモデ ルを用いた風洞実験で，空中期のジャンパーに働 く空力特性を分析した.V字スタイルとパラレル スタイルのジャンパーに働く空気力を比較した結 果，スキージャンパーの飛翔方向とスキー板のな す迎え角が,小さい時の両スタイルに打ける抗力, 揚力に差はないが，迎え角が大きくなると，飛翔 方向に対する投影面積等が増加し，抗力，揚力の 差が増大することを明らかにした。また，着地直 前の地面効果も抗力の減少と揚力の増加を引き起 こし，特にV 字スタイルで飛距離の増加に大き く貢献することを示した.さらに両スタイルとも， ピッチングモーメントの迎え角依存性が右下がり で，かつ，ピッチングモーメントが迎え角の増加 とともにプラスからマイナスに変化する場合，空 中期にピッチング振動（oscillation）が起きる可 能性があることが示唆された。

伊藤（2004）は，水泳のプルに関する風洞実験 の結果や数值解析より, 推進効率がよいとされて きた $\mathrm{S}$ 字型プルは，エネルギー効率は確かによい が, 最大推力では抗力型プルの方が大きいことを 示した。そして，肩部筋肉の負担や疲労等を考え ない場合，中距離，短距離種目では，最大推力が 発揮できる抗力型プルにした方が推進力を大きく できる可能性が高いことを指摘している.

また，流体の挙動に関する計算科学的手法とし 
て, 数值流体力学 (Computer Fluid Dynamics：CFD）による数值解析もスポーツ分野に活 用されるようになってきている（浅井，2004）。 モデリング方法として, 解析対象のシステムや物 体の数值モデルを作成し, 数值計算によって流れ や挙動を予測していくところは, 有限要素法 (FEM) と類似しているが, FEMが解析対象の 構造体にメッシュを定義するのに対して，CFD では，流れが起きる物体の周りや内部の流体その ものにメッシュを定義することになる，CFDは， 物体周りや内部の流れの動きを予測するだけでな く, 熱伝達, 質量 (蒸散や溶解など), 相の変化 (凍結や沸騰など), 化学反応 (燃焼など), 動き を伴う流れ（水泳ストローク中における手の周り の流れ（図 7）など), 流れによる応力や固体の 変形（風によるマストのツイストなど）なども計 算可能である.

CFDのメリットとしては, CFD を用いること によって解析対象の力やモーメント, 圧力分布が 計算できるだけでなく, 流れ場を可視化すること ができ，その現象を視覚的に把握することができ る点にある。また，境界条件や初期条件を容易に 変えることができ, 数值実験的にパラメータスタ ディが行なえるので, 様々なケースの現象が予測 可能となる．流れ場をある程度妥当に予測するこ とができれば, その解析モデルや解析結果をもと にシステムの最適化が検討可能となる。一般に沉 用 CFDソルバーは, 有限体積法を用いており, Fluent 6.2 (Fluent Inc.), STAR-CD (CD adapco Japan Co.) 等が知られているが, 流体ソルバ 一は計算方法や流体モデルによって多くの種類が あり，それぞれ得意な分野があると考えられるの で, 目的に応じて適当なソルバーや流体モデルを 選択することが重要になってくる．また，スポー ツに関する流れ場を解析する場合，乱流や渦，境 界層の剥離等が問題になる場合が多い。したがっ て，解析に用いる乱流モデルに何を選択するかも 重要なポイントである。ここ数十年間の CFD 分 野では, レイノルズ平均ナビエ-ストーク (Reynolds Averaged Navier-Stokes : RANS) 乱流モデルを用いた定常解析が様々な分野で大き

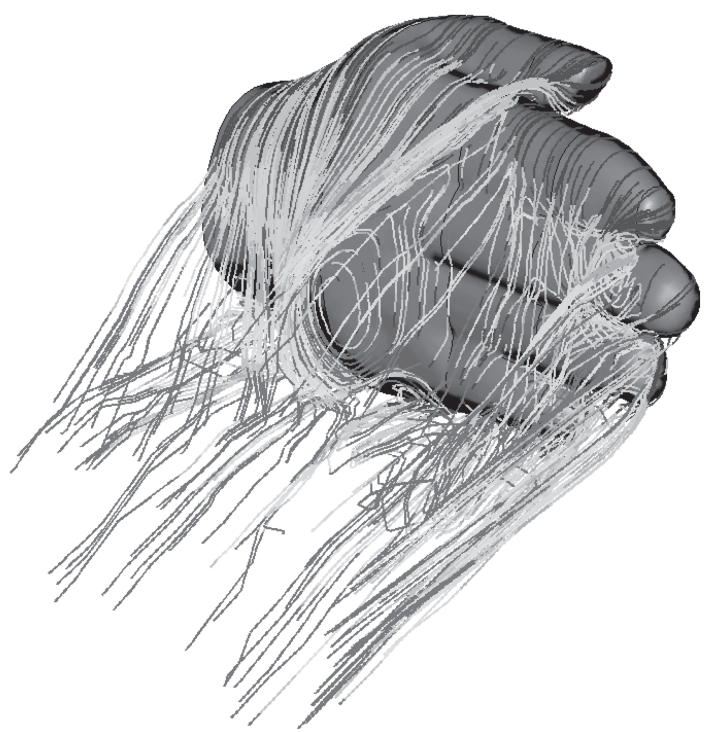

図 7 水泳のプルに関する CFD 解析例. ダイナミックメ ッシュ技術（物体の位置座標が変わると自動的にメッシ ユを再構築する技術）により，流体の中を手が運動し， その際の圧力分布や流速分布が計算できる. (Image courtesy of Fluent inc.)

な成果を上げ，その応用性が実証されている。し かし, 問題によっては, 非定常な動態を知る必要 があり，近年では，非定常解析にラージエディシ ミュレーション (Large Eddy Simulation : LES) 乱流モデルが使われてきている，また，莫大な計 算資源が必要ではあるが，ナビエ-ストーク方程 式を直接数值計算する直接数值シミュレーション 法（Direct Numerical Simulation : DNS）も試 みられている。この, RANS モデルやLES モデ ルをはじめ, 多くの乱流モデルやその関連亜流モ デル，合成モデルがあり，それぞれ特性や適性が あるので，それを充分検討した上で選択すること が必要である。

$\mathrm{V}$ 字スキージャンパー周りの流れを CFD で解 析した例（浅井ほか, 1998）では, RNGk- $\varepsilon$ 乱流 モデルを用いて定常解析を行なっており, 揚抗比 や圧力分布, 流速分布等が検討されている(図 8). その結果, 風洞実験值と同様の揚抗比が得られ, 迎え角 20 度付近が最大揚抗比になることを示し た.また, ジャンパー周りの圧力分布, 流速分布 

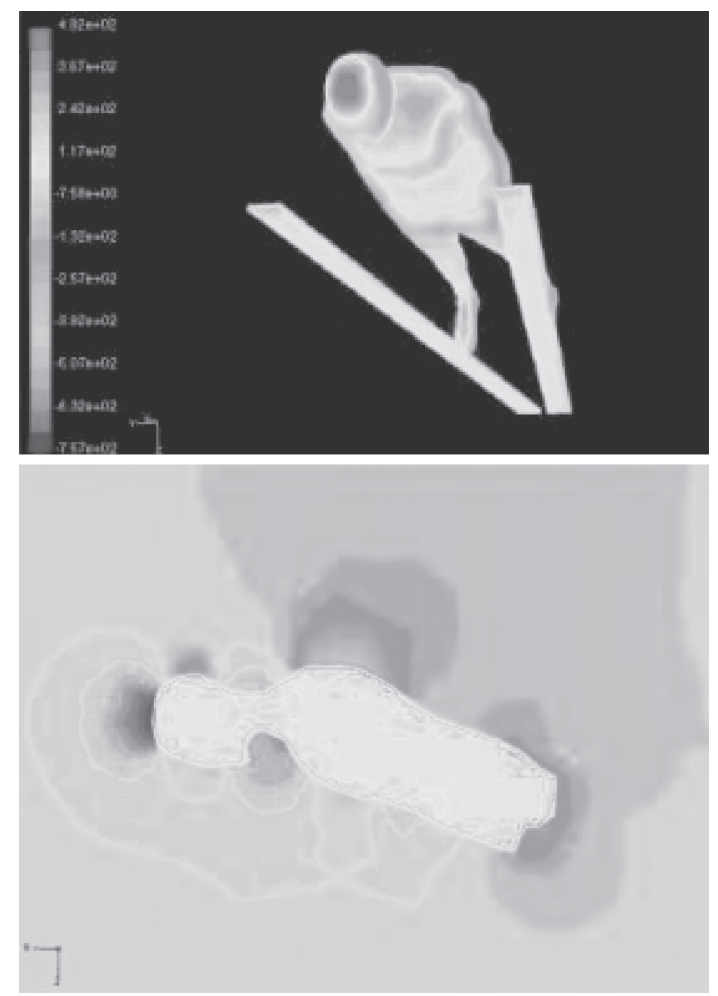

図8 スキージャンパーモデル（数学モデル）を用いた数 值流体解析例. ジャンパー表面の圧力分布（上）だけで なく, 周りの流体の圧力 (下) や流速等も計算し可視化 できる.

等から, 頭部, 肩部, 足部に高い圧力, 後背部に 高い陰圧がみられ，渦のみられる首部周りの流れ を整流化することで, 空気抵抗が下がる可能性が あると考えられた。

スポーツに関するCFDは，体育領域では事例 が少ないが，スポーツ工学領域では，かなり盛ん に研究されるようになってきた。これまで, 軍事 や医療, 製造業が中心となって CFD が発展して きたが，今後は，スポーツ関連領域でも，便利な ツールとして研究・開発に活用されていくと予測 される（例えばhttp://www.fluent.co.jp/ contents/kaiseki/industry/sports/index.html を 参照).

\section{V ま と め}

身体運動やスポーツ技術を，バイオメカニクス 的, あるいは工学的に検討する場合によく用いら れる力学系モデルを, 剛体系モデル, 変形体系モ デル, 流体系モデルの順に概観した. 質量一バネ モデルやリンク・セグメントモデルに代表される 剛体系モデルは，これまで体育・スポーツ分野の 中心的モデルであり, 今後も進歩し続け, 様々な 問題に適用されると考えられる。それと同時に, 剛体系モデルでは上手く適合しない現象があるの も事実であり, それらの研究や問題解決には, 変 形体系モデル, 流体系モデルが役立つことも多い. 例えば，ランニング着地時の足とグランドの接触 問題を分析しょうとするとき, 剛体で足やグラン ドをモデリングすると, 剛体同士の接触というこ とで, 接触時間は一瞬となり, 実現象とは異なる. それを回避するために, 接触関数をいろいろ工夫 することが多いが，接触自体を分析しょうとする 場合, 分析対象自体を自分が定義するという矛盾 に陥る可能性もある。これらは, 変形体系のモデ ルで分析した方が合理的であり, 実際, ランニン グシューズの設計等には, 変形体系モデルが活用 されている.

これまでの体育・スポーツ分野のモデルを用い た分析では, 実際の運動座標值から運動学的デー 夕を基に逆動力学 (変位を入力し, 力を出力する) で関節トルク等を求めて現象を詳細に「記述」す るというアプローチが主流であり，それで大きな 成果を上げてきた。そのような逆動力学による 「記述」と同時に, 発揮する力をべースとした順 動力学 (力を入力し, 変位を出力する) を用いた 分析も,「予測」が行い易いという意味で必要で ある.そして, 妥当なレベルで現象の「予測」が できることによって, 現象の「最適化」(Seo et al., 2004b）が可能となる.この「記述」「予測」 「最適化」を念頭に入れたモデリングが大切にな ると考えられる。

また，これまでのアプローチでは，一つの現象 やシステムに対して一つのモデルを対応させるこ 
とが主流であった。しかし，今後は，剛体系一流 体系モデル，制御系一サーボ系モデル，心理系一 力学系モデル等のように, 幾つかのモデルを連成 させたり, 関連させて分析, 問題解決するマルチ フィジックス，マルチモデリングなどのアプロー チも重要になってくると思われる.

\section{VI 付 記}

本研究の一部は文部科学省の科研費 (17300200) の助成を得たものである.

\section{文献}

阿江通良・藤井範久 (2002) スポーツバイオメカニ クス 20 講. 朝倉書店 : 東京.

浅井 武・村上広高（1998） スキーのV 字ジャンプ に関する数值流体解析. デサントスポーツ科学, $19: 246-253$.

Asai, T. and Murakami, H. (2001) Development and evaluation of a finite element foot model. Proc. of the 5thSymposium on Footwear Biomechanics, 6 : $10-11$.

Asai, T., Nishiwaki, T., and Nunome, H. (2001) Prototype of a finite element foot model. Proc. of the Seventh Japan International SAMPE Symposium, 7: 439-442.

Asai, T., Carré M.J., Akatsuka, T., and Haake, S.J. (2002) The curve kick of a football, I: impact with the ball. Sports Engineering, 5 (4): 183-192.

Asai, T., Takano, S., Carré M.J., and Haake, S.J. (2004) A fundamental study of an infront curve kick in football. In: Hubbard, M., Mehta, R., and Pallis, J.M. (Eds.) The Engineering of Sport 5 Vol. (2). Central Plains Book Mfg: KS, pp. 290-295.

浅井 武 (2004) 有限要素法 (FEM) と数值流体力 学 (CFD) のスポーツへの応用. バイオメカニク 久研究, 8 (3) : 164-171.

Asai, T., Nunome, H., Maeda, A., Matsubara S., and Lake, M. (2005) Computer Simulation of Ball Kicking using the Finite Element Skeletal Foot Model. In: Reilly, T., Cabri, J., and Araujo, D. (Eds.) Proc. of the Fifth World Congress on Science and Football. Routledge: Cornwall, pp. 77-82.
Briggs, L.J. (1959) Effect of spin and speed on the lateral deflection (curve) of a baseball; and the Magnus effect for smooth spheres. Am. J. Phys., 27: 589 -596 .

Haug, E.J. (1995) Computer-Aided Kinematics and Dynamics of Machanical Systems. Volume1: Basic Methods. Allyn and Bacon, Inc.: Boston.

Heglund, N.C., Willems, P.A., Penta, M., and Cavagna, G.A. (1995) Energy-saving gait mechanics with head-supported loads. Nature, 375: 52-54.

Huiskes, R. and Chao, E.Y.S. (1983) A survey of finite element analysis in orthopedic biomechanics: the first decade. J. Biomech., 16 (6): 385-409.

深代千之（2000）スポーツバイオメカニクスへの招 待. 深代千之ほか編 スポーツバイオメカニクス. 朝倉書店：東京, pp. 1-8.

Hoy, M.G., Zajac, F.E., and Gordon, M.E. (1992) A musculoskeletal model of the human lower extremity: The effect of muscle, tendon, and moment arm on the moment-angle relationship of musculotendon actuators at the hip, knee, and ankle. J. Biomech., 23 (2): 157-169.

伊藤 章 - 市川博敬 - 斉藤昌久 - 佐川和則 - 伊藤道 郎・小林寛道（1998）100m 中間疾走局面における 疾走動作と速度との関係. 体育学研究, 43：260273.

伊藤慎一郎（2004）手のひらの推進力と身体の抵抗 からみた最速の泳法. 科学, 74（6）：734-739.

川上泰雄（2003）運動中の筋繊維収縮動態。バイオ メカニズム学会誌，27：67-71.

Matsuo, T., Matsumoto, T., Mochizuki, Y., Takada, Y., and Saito, K. (2002) Optimal shoulder abduction angles during baseball pitching from a maximal performance and minimal kinetics viewpoints. J. Appl. Biomech., 18: 306-320.

Mehta, R.D., Bentley, K., Proudlove, M., and Varty, P. (1983) Factors affecting cricket ball swing. Nature, 303: 787-788.

宮西智久 - 藤井範久 - 阿江通良 - 功刀靖雄 - 岡田守 彦（1997）野球の投球動作における体幹および投 球腕の力学的エネルギーフローに関する 3 次元解 析. 体力科学, $46: 55-68$.

Nagano, A. and Gerritsen, K.G.M. (2001) Effects of neuromuscular strength training on vertical jump- 
ing performance - a computer simulation study-. J. Appl. Biomech., 17: 113-128.

長野明紀, 深代千之（2003）Hill型腱筋複合体のモデ

リングとコンピュータシミュレーション。 バイオ

メカニクス研究, 7 (3) : 225-238.

中部 昇・西脇剛史（1998）シューズの特性評価を

目的とした下肢の数值モデルの提案. 日本機械学

会スポーツ工学シンポジウム講演論文集, 98-

31 : 17-20.

Nunome, H., Asai, T., Ikegami, Y., and Sakurai, S. (2002) Three-dimensional kinetic analysis of sidefoot and instep soccer kicks. Med. Sci. Sports Exerc., 34: 2028-2036.

Sakashita, R., Asai, T., and Takizawa, K. (2002) A fundamental study on relation between impression and movement. In: Ujihashi, S. and Haake, S.J. (Eds.) The Engineering of Sport 4. Blackwell Science: Cornwall, pp. 810-816.

Sakurai, S., Ikegami, Y., Okamoto, A., Yabe, K., and Toyoshima, S. (1993) A three-dimensional cinematographic analysis of upper limb movement during fastball and curveball baseball pitches. J. Appl. Biomech., 9: 47-63.

Seo, K., Watanabe, I., and Murakami, M. (2004a) Aero- dynamic force data for a $\mathrm{V}$-style ski jumping flight. Sports Engineering., 7 (1): 31-39.

Seo, K., Watanabe, I., Murakami, M., and Yoshida K. (2004b) Optimal flight of a V-style ski jumping. Sports Engineering., 7 (2): 97-103.

Seyfarth, A., Geyer, H., Gänther, M., and Blickhan, R. (2002) A movement criterion for running. J. Biomech., 35: 649-655.

島田一志 - 阿江通良 - 藤井範久 - 川村 卓 - 高橋佳 三（2004）野球のピッチング動作における力学的 エネルギーの流れ。バイオメカニクス研究, 8 (1) : 12-26.

谷 一郎（1980）流れ学 第3版. 岩波全書: 東京.

戸川隼人（1979）有限要素法へのガイド。サイエン ス社：東京, pp. 1-18.

Toussaint, H.M., Janssen, T., and Kluft, M. (1991) Efect of propelling surface size on the mechanics and energetics of front crawl swimming. J. Biomech., 24: 205-211.

Winter, D.A. (1990) Biomechanics and Motor Control of Human Movement 2nd ed. John Wiley \& Sons: IN.

$\left(\begin{array}{l}\text { 平成 } 17 \text { 年 } 9 \text { 月 } 13 \text { 日受付 } \\ \text { 平成 } 18 \text { 年 } 1 \text { 月 } 14 \text { 日受理 }\end{array}\right)$ 